Humanistika: Jurnal Keislaman

Vol. 7 No 2 2021. Hal. 1-25 ISSN (Print): 2460-5417ISSN (Online): 2548-4400

DOI: https://doi.org/10.36835/humanistika.v7i2.522

\title{
ISLAM DI SPANYOL : JEMBATAN PERADABAN ISLAM KE BENUA EROPA DAN PENGARUHNYA TERHADAP RENAISSANCE
}

\author{
Irzak Yuliardy Nugroho \\ Universitas Islam Zainul Hasan Genggong \\ ardhiesjb@gmail.com \\ Riani Muarafah Jannati \\ Universitas Islam Zainul Hasan Genggong \\ rianimuarofah@gmail.com
}

\begin{abstract}
When Islam began to enter a period of deterioration, at the end of the classical period of Islam. This revival was seen not only in the political sphere with Europe's success in defeating Islamic empires and other parts of the world, but especially in the fields of science and technology. In fact, it is advances in science and technology that have supported his political success. These European advances cannot be separated from the Islamic government in Spain. From Islam, Spain in Europe got a lot of knowledge. In the classical period, when Islam was reaching its golden age, Spain was a very important center of Islamic civilization, rivaling Baghdad in the East. At that time, many Christian Europeans studied in Islamic universities there. Islam became a teacher for Europeans. Therefore, the presence of Islam in Spain has attracted the attention of many researchers to find out more about Islamic civilization in Spain.
\end{abstract}

Keywords: Islam, Civilization, Renaissance

https:/ / ejournal.unzah.ac.id/index.php/humanistika 


\begin{abstract}
Abstrak
Ketika Islam mulai memasuki masa kemunduran, pada masa berakhirnya periode klasik Islam. Eropa bangkit dari keterbelakangannya. Kebangkitan itu bukan saja terlihat dalam bidang politik dengan keberhasilan Eropa mengalahkan kerajaankerajaan Islam dan bagian dunia lainnya, tetapi terutama dalam bidang ilmu pengetahuan dan teknologi. Bahkan, kemajuan dalam bidang ilmu dan teknologi itulah yang mendukung keberhasilan politiknya. Kemajuan-kemajuan Eropa ini tidak dapat dipisahkan dari pemerintahan Islam di Spanyol. Dari Islam Spanyol di Eropa banyak menimba Ilmu. Pada periode klasik, ketika Islam mencapai masa keemasannya, Spanyol merupakan pusat peradaban Islam yang sangat penting, menyaingi Baghdad di Timur. Ketika itu, orang-orang Eropa Kristen banyak belajar di perguruan-perguruan tinggi Islam di sana. Islam menjadi guru bagi orang-orang Eropa. Karena itu, kehadiran Islam di Spanyol banyak menarik perhatian peneliti untuk mengetahui lebih jauh tentang peradaban Islam di Spanyol.
\end{abstract}

\title{
Kata Kunci : Islam, Peradaban, Renaissance
}

Humanistika: Vol. 7 No. 22021. 


\section{Islam di Spanyol : Jembatan Peradaban Islam ke Benua Eropa dan Pengaruhnya Terhadap Renaissance}

\section{PENDAHULUAN}

Andalusia yang sekarang bernama Spanyol, adalah sebutan bagi semenanjung Iberia periode Islam. Sebutan itu berasal dari kata V andalusia, yang berarti negeri bangsa Vandal, karena bagian selatan semenanjung itu pernah dikuasai bangsa Vandal sebelum mereka diusir oleh bangsa Gothia Barat pada abad V Masehi. Bani Umayyah merebut semenanjung ini dari bangsa Gothia Barat pada zaman Khalifah Al Walid (705-715 M), salah seorang khalifah dari Bani Umayah yang berpusat di Damaskus. ${ }^{1}$ Sebelum penaklukan Spanyol, umat Islam telah menguasai Afrika Utara dan menjadikannya sebagai salah satu propinsi dari dinasti Bani Umayah. Penguasaan sepenuhnya atas Afrika Utara itu terjadi di zaman Khalifah Abdul Malik (685-705 M). Khalifah Abd Al-Malik mengangkat Hasan ibn Nu'man Al-Ghassani menjadi gubernur di daerah itu. Pada masa Khalifah Al-Walid, Hasan ibn Nu'man sudah digantikan oleh Musa ibn Nushair. Di zaman Al-Walid itu, Musa ibn Nushair memperluas wilayah kekuasaannya dengan menduduki Aljazair dan Marokko. Selain itu, ia juga menyempurnakan penaklukan ke daerah-daerah bekas kekuasaan bangsa Barbar di pegunungan-pegunungan, sehingga mereka menyatakan setia

${ }^{1}$ Siti Maryam et.al, Sejarah Peradaban Islam: Dari Masa Klasik Hingga Modern, (Yogyakarta: LESFI, 2012), 79.

Humanistika: Vol. 7 No. 22021. 


\section{Irzak Yuliardy Nugroho}

dan berjanji tidak akan membuat kekacauan-kekacauan seperti yang pernah mereka lakukan sebelumnya.

Penaklukan atas wilayah Afrika Utara itu pertama kali dikalahkan sampai menjadi salah satu propinsi dari Khilafah Bani Umayah memakan waktu selama 53 tahun, yaitu mulai tahun $30 \mathrm{H}$ (masa pemerintahan Muawiyah ibn Abi Sufyan) sampai tahun $83 \mathrm{H}$ (masa Al-Walid). ${ }^{2}$ Sebelum dikalahkan dan kemudian dikuasai Islam, di kawasan ini terdapat kantungkantung yang menjadi basis kekuasaan kerajaan Romawi, yaitu kerajaan Gothik. Kerajaan ini sering menghasut penduduk agar membuat kerusuhan dan menentang kekuasaan Islam. Setelah kawasan ini betulbetul dapat dikuasai, umat Islam memulai memusatkan perhatiannya untuk menaklukan Spanyol. Dengan demikian, Afrika Utara menjadi batu loncatan bagi kaum Muslimin dalam penaklukan wilayah Spanyol.

Dalam proses penaklukan Spanyol terdapat tiga pahlawan Islam yang dapat dikatakan paling berjasa memimpin satuan-satuan ke sana. Mereka adalah Tharif ibn Malik, Thariq ibn Ziyad, dan Musa ibn Nushair. Tharif dapat disebut sebagai perintis dan penyelidik. Ia menyeberangi selat yang berada di antara Maroko dan benua Eropa itu dengan satu pasukan

\footnotetext{
${ }^{2}$ A. Syalabi, Sejarah dan Kebudayaan Islam, Jilid II Cet. I (Jakarta: Pustaka Alhusna, 1983), 154.
}

Humanistika: Vol. 7 No. 22021. 


\section{Islam di Spanyol : Jembatan Peradaban Islam ke Benua Eropa dan Pengaruhnya Terhadap Renaissance}

perang, lima ratus orang di antaranya adalah tentara berkuda, mereka menaiki empat buah kapal yang disediakan oleh Julian. ${ }^{3}$ Dalam penyerbuan itu Tharif tidak mendapat perlawanan berarti. Ia menang dan kembali ke Afrika Utara membawa harta rampasan yang tidak sedikit jumlahnya. Didorong oleh keberhasilan Tharif dan kemelut yang terjadi dalam tubuh kerajaan Visighotic yang berkuasa di Spanyol pada saat itu, serta dorongan yang besar untuk memperoleh harta rampasan perang, Musa ibn Nushair pada tahun $711 \mathrm{M}$ mengirim pasukan ke Spanyol sebanyak 7000 orang di bawah pimpinan Thariq ibn Ziyad.

Thariq ibn Ziyad lebih banyak dikenal sebagai penakluk Spanyol, karena pasukannya lebih besar dan hasilnya lebih nyata. Pasukannya terdiri dari sebagian besar suku Barbar yang didukung oleh Musa ibn Nushair dan sebagian lagi orang Arab yang dikirim Khalifah Al-Walid. Pasukan itu kemudian menyeberangi Selat di bawah pimpinan Thariq ibn Ziyad. ${ }^{4}$ Sebuah gunung tempat pertama kali Thariq dan pasukannya mendarat dan menyiapkan pasukannya, dikenal dengan nama Gibraltar (Jabal Thariq). Dengan dikuasainya daerah ini, maka terbukalah pintu secara luas untuk memasuki Spanyol. Dalam pertempuran di suatu tempat yang bernama

\footnotetext{
${ }^{3}$ A. Syalabi, Sejarah dan Kebudayaan Islam, 158.

${ }^{4}$ Carl, Brockelmaan, History of the Islamic Peoples, (London: Rotledge \& Kegan Paul, 1980), hlm. 83.
}

Humanistika: Vol. 7 No. 22021. 


\section{Irzak Yuliardy Nugroho}

Bakkah, Raja Rederick dapat dikalahkan. Dari situ Thariq dan pasukannya terus menaklukan kota-kota penting, seperti Cordova, Granada, dan Toledo (ibu kota kerajaan Goth saat itu). Sebelum Thariq menaklukan kota Toledo, ia meminta tambahan pasukan kepada Musa ibn Nushair di Afrika Utara. Musa mengirimkan tambahan pasukan sebanyak 5000 personel, sehingga jumlah pasukan Thariq seluruhnya 12.000 orang. Jumlah ini belum sebanding dengan pasukan Gothik yang jauh lebih besar, 100.000 orang.

Kemenangan pertama yang dicapai oleh Thariq ibn Ziyad membuka jalan untuk penaklukan wilayah yang lebih luas lagi untuk itu, Musa ibn Nushair merasa perlu melibatkan diri dalam gelanggang pertempuran dengan maksud membantu perjuangan Thariq. Dengan suatu pasukan yang besar, ia berangkat menyeberangi selat itu dan satu per satu kota yang dilewatinya dapat ditaklukannya. Setelah Musa berhasil menaklukan Sidonia, Karmona, Seville, dan Merida serta mengalahkan serta mengalahkan penguasa kerajaan Ghotic, Theodomir di Orihuela, ia bergabung dengan Thariq di Toledo. Selanjutnya, keduanya berhasil menguasai seluruh kota penting di Spanyol, termasuk bagian utaranya, mulai dari Saragosa sampai Navarre.

Humanistika: Vol. 7 No. 22021. 


\section{Islam di Spanyol : Jembatan Peradaban Islam ke Benua Eropa dan Pengaruhnya Terhadap Renaissance}

Kemenangan-kemenangan yang dicapai umat Islam nampak begitu mudah. Hal ini tidak dapat dipisahkan dari adanya faktor eksternal dan internal yang menguntungkan. Yang dimaksud dengan faktor eksternal adalah suatu kondisi yang terdapat di dalam negeri Spanyol sendiri. Pada masa penaklukan Spanyol oleh orang-orang Islam, kondisi sosial, politik dan ekonomi negeri yang berada dalam keadaan menyedihkan. Secara politik wilayah Spanyol terkoyak-koyak dan terbagi dalam beberapa negara kecil. Bersamaan dengan itu, penguasa Gothic bersikap tidak toleran terhadap aliran agama yang dianut oleh penguasa, yaitu aliran monofisit, apalagi terhadap penganut agama lain, Yahudi. Penganut agama Yahudi yang merupakan bagian terbesar dari penduduk Spanyol dipaksa dibaptis menurut agama Kristen. Yang tidak bersedia disiksa dan dibunuh secara brutal. ${ }^{5}$

Perpecahan dalam negeri Spanyol ini banyak membantu keberhasilan campur tangan Islam di tahun 711 M. Perpecahan itu amat banyak coraknya dan sudah ada jauh sebelum kerjaan Gothic itu berdiri. Perpecahan politik memperburuk keadaan ekonomi masyarakat Spanyol. Ketika Islam masuk ke Spanyol, ekonomi masyarakat dalam keadaan lumpuh. Padahal, sewaktu Spanyol berada dibawah pemerintahan

${ }^{5}$ Thomas W. Arnold, Sejarah Da'wah Islam, (Jakarta: Wijaya, 1983), 118

Humanistika: Vol. 7 No. 22021. 


\section{Irzak Yuliardy Nugroho}

Romawi, berkat kesuburan tanahnya, pertanian maju pesat. Demikian juga pertambangan, industri, dan perdagangan karena didukung oleh sarana transportasi yang baik. Akan tatapi, setelah Spanyol berada dalam kekuasaan kerajaan Goth perekonomian lumpuh dan kesejahteraan rakyat menurun. Hektaran tanah dibiarkan terlantar tanpa digarap, beberapa pabrik ditutup, dan antara satu daerah dengan daerah lain sulit dilalui akibat jalan-jalan tidak mendapat perawatan.

Adapun yang dimaksud dengan faktor internal adalah suatu kondisi yang terdapat dalam tubuh penguasa, tokoh-tokoh pejuang, dan prajurit Islam yang terlibat dalam penaklukan wilayah Spanyol pada khususnya. Para pemimpin adalah tokoh-tokoh yang kuat, tentaranya kompak, bersatu, dan penuh percaya diri. ${ }^{6}$ Mereka pun cakap, berani, dan tabah dalam menghadapi setiap persoalan. Yang tak kalah pentingnya adalah ajaran Islam yang ditunjukan pada tentara Islam, yaitu toleransi, persaudaraan, dan tolong menolong. Sikap toleransi agama dan persaudaraan yang terdapat dalam pribadi kaum Muslimin itu menyebabkan penduduk Spanyol menyambut kehadiran Islam di sana. ${ }^{7}$

${ }^{6}$ Thomas W. Arnold, Sejarah Da'wah Islam, 125.

${ }^{7}$ Badri Yatim, Sejarah Peradaban Islam, (Jakarta: PT Rajagrafindo Persada, 2006), 93.

Humanistika: Vol. 7 No. 22021. 
Islam di Spanyol : Jembatan Peradaban Islam ke Benua Eropa dan Pengaruhnya Terhadap Renaissance

\section{PEMBAHASAN}

\section{Perkembangan Islam di Spanyol}

Sejak pertama kali menginjakkan kaki di tanah Spanyol hingga tiba masa jatuhnya kerajaan Islam terakhir di sana, Islam telah memainkan peranan yang sangat besar. Masa itu berlangsung lebih dari tujuh setengah abad. Sejarah panjang yang telah dilalui oleh umat Islam di Spanyol dapat dibagi menjadi enam periode, yaitu:

a. Periode Pertama (711-755M)

Pada periode ini, Spanyol berada di bawah pemerintahan para wali yang diangkat oleh Khalifah Bani Umayah yang berpusat di Damaskus. Pada periode ini stabilitas politik negeri Spanyol belum tercapai secara sempurna,gangguan-gangguan masih terjadi, baik datang dari dalam maupun dari luar. Gangguan dari dalam antara lain berupa perselisihan di antara elit penguasa, terutama akibat perbedaan etnis dan golongan. Di samping itu, terdapat perbedaan pandangan antara Khalifah di Damaskus dan gubernur Afrika Utara yang berpusat di Kairawan. Masing-masing mengaku bahwa, merekalah yang paling berhak menguasai daerah Spanyol ini. Oleh karena itu, terjadi dua puluh kali pergantian wali (gubernur) Spanyol dalam waktu yang amat singkat. Perbedaan pandangan politik itu menyebabkan sering terjadi perang saudara.

Humanistika: Vol. 7 No. 22021. 


\section{Irzak Yuliardy Nugroho}

Gangguan dari luar datang dari sisa-sisa musuh Islam di Spanyol yang bertempat tinggal di daerah-daerah pegunungan yang memang tidak pernah tunduk kepada pemerintahan Islam. Gerakan ini terus memperkuat diri. Setelah berjuang lebih dari 500 tahun, akhirnya mereka mampu mengusir Islam dari bumi Spanyol.

Karena seringnya terjadi konflik internal dan menghadapi musuh dari luar, maka dalam periode ini Islam Spanyol belum memulai pembangunan di bidang peradaban dan kebudayaan. Periode ini berakhir dengan datangnya Abd al-Rahman al-Dakhil ke Spanyol pada $138 \mathrm{H} / 755 \mathrm{M}^{8}$

b. Periode Kedua (755-912 M)

Pada periode ini, umat Islam Spanyol mulai memperoleh kemajuan-kemajuan, baik dalam bidang politik maupun dalam bidang peradaban. Abd Al-Rahman Al-Dakhil mendirikan masjid Cordova dan sekolah-sekolah di kota-kota besar di Spanyol. Hisyam dikenal berjasa dalam penegakan hukum Islam dan Hakam dikenal sebagai pembaharu dalam bidang kemiliteran. Dialah yang memperkasai tentara bayaran di Spanyol. Sedangkan Abd Al-Rahman Al-Ausath dikenal sebagai penguasa yang cinta ilmu.

\footnotetext{
${ }^{8}$ Badri Yatim, Sejarah Peradaban Islam, 94.
}

Humanistika: Vol. 7 No. 22021. 


\section{Islam di Spanyol : Jembatan Peradaban Islam ke Benua Eropa dan Pengaruhnya Terhadap Renaissance}

Sekalipun demikian, berbagai ancaman dan kerusuhan terjadi. Pada pertengahan abad ke-9, stabilitas negara terganggu dengan munculnya gerakan Kristen fanatik yang mencari Kesyahidan. Namun, Gereja Kristen lainnya diseluruh Spanyol tidak menaruh simpati pada gerakan itu, karena pemerintah Islam mengembangkan kebebasan beragama. Penduduk Kristen diperbolehkan memiliki pengadilan sendiri berdasarkan hukum Kristen. ${ }^{9}$

c. Periode Ketiga (912-1013 M)

Periode ini berlangsung mulai dari pemerintahan $\mathrm{Abd} \mathrm{Al}$ Rahman III yang bergelar "An-Nasir sampai munculnya "raja-raja kelompok" yang dikenal dengan sebutan Muluk al-Thawaif. Pada periode ini, umat Islam Spanyol mencapai puncak kemajuan dan kejayaan, menyaingi kejayaan daulat Abbasiyah di Baghdad. Abd AlRahman Al- Nashir mendirikan Universitas Cordova. Perpustakaannya memiliki koleksi ratusan ribu buku. Hakam II juga seorang kolektor buku dari pendiri perpustakaan. Pada masa ini, masyarakat dapat menikmati kesejahteraan dan kemakmuran. Pembangunan kota berlangsung cepat. ${ }^{10}$

${ }^{9}$ Badri Yatim, Sejarah Peradaban Islam, 96.

${ }^{10}$ Badri Yatim, Sejarah Peradaban Islam, 97.

Humanistika: Vol. 7 No. 22021. 


\section{Irzak Yuliardy Nugroho}

Awal dari kehancuran Khalifah Bani Umayah di Spanyol adalah ketika Hisyam naik tahta dalam usia sebelas tahun. Oleh karena itu, kekuasaan aktual berada pada tangan para penjabat. Pada tahun 981 M, Khalifah menunjuk Ibn Abi' Amir sebagai pemegang kekuasaan secara mutlak. Dia seorang yang ambisius yang berhasil menancapkan kekuasaannya dan melebarkan wilayah kekuasaan Islam dengan menyingkirkan saingan-saingan dan rekan-rekannya. Atas keberhasilannya, ia mendapat gelar Al-Manshur Billah. Ia wafat pada tahun 1002M dan digantikan oleh anaknya Al-Muzaffar, yang masih dapat mempertahankan keunggulan kerajaan. Akan tetapi, setelah wafat pada tahun 1008 M, ia digantikan oleh adiknya yang tidak memiliki kualitas bagi jabatan itu. Dalam beberapa tahun saja, negara yang tadinya makmur dilanda kekacauan dan akhirnya kehancuran total. Pada tahun 1009 M khalifah mengundurkan diri. Beberapa orang yang dicoba untuk menduduki jabatan itu tidak ada yang sanggup memperbaiki keadaan. Akhirnya, pada tahun 1013 M, Dewan Menteri yang memerintah Cordova menghapuskan jabatan Khalifah. Ketika itu, Spanyol sudah terpecah dalam banyak sekali negara kecil yang berpusat di kota-kota tertentu. ${ }^{11}$

11 W. Montgomery Watt, Kejayaan Islam: Kajian Kritis dari Tokoh Orientalis, (Yogyakarta: Tiara Wacana, 1990), 217-218.

Humanistika: Vol. 7 No. 22021. 


\section{Islam di Spanyol : Jembatan Peradaban Islam ke Benua Eropa dan Pengaruhnya Terhadap Renaissance}

d. Periode Keempat (1013-1086 M)

Pada periode ini, Spanyol terpecah menjadi lebih dari tiga puluh negara kecil di bawah pemerintahan raja-raja golongan yang berpusat di suatu kota seperti Seville, Cordova, Toledo, dan sebagainya. Yang terbesar diantaranya adalah Abbadiyah di Seville. Pada peroide ini umat Islam Spanyol kembali memasuki masa pertikaian intern. Ironisnya, kalau terjadi perang saudara, ada di antara pihak-pihak yang bertikai itu yang meminta bantuan kepada raja-raja Kristen. Melihat kelemahan dan kekacauan yang menimpa keadaan politik Islam itu, untuk pertama kalinya orang-orang Kristen pada periode ini mulai mengambil inisiatif penyerangan. Meskipun, kehidupan politik tidak stabil, namun, kehidupan intelektual terus berkembang pada periode ini. Istana-istana mendorong para sarjana dan sastrawan untuk mendapatkan perlindungandari suatu istana ke istana lain. ${ }^{12}$

e. Periode Kelima (1086-1248M)

Pada periode ini, Spanyol Islam meskipun masih terpecah dalam beberapa negara, tetapi terdapat satu kekuatan yang dominan, yaitu kekuasaan dinasti Murabithun (1086-1143 M) dan dinasti Muwahiddun (1146- 1235 M). Dinasti Murabithun pada mulanya

${ }^{12}$ Badri Yatim, Sejarah Peradaban Islam, 98.

Humanistika: Vol. 7 No. 22021. 


\section{Irzak Yuliardy Nugroho}

adalah gerakan agama yang didirikan oleh Yusuf ibn Tasyfin di Afrika Utara. Ia masuk ke Spanyol atas undangan penguasa-penguasa Islam pada saat itu yang tengah memikul beban berat perjuangan mempertahankan negeri-negerinya dari serangan orang-orang Kristen. Ia dan tentaranya masuk ke Spanyol pada tahun 1086 M dan berhasil mengalahkan pasukan Castilla. Akan tetapi, penguasa-penguasa sesudah ibn Tasyfin adalah raja-raja yang lemah. Pada tahun 1143 M, kekuasaan dinasti ini berakhir dan digantikan dengan dinasti Muwahiddun, pada tahun $1146 \mathrm{M}$ penguasa dinasti Muwahiddun yang berpusat di Afrika Utara merebut daerah ini. Dinasti ini datang ke Spanyol di bawah pimpinan Abd Al Mun'im. Antara tahun 1114 dan 1154 M, kota-kota muslim penting, Cordova, Almeria, Granada, jatuh kebawah kekuasaannya. Untuk jangka beberapa dekade, dinasti ini mengalami banyak kemajuan. Kekuatan-kekuatan Kristen dapat dipukul mendur. Akan tetapi, tidak lama setelah itu, Muwahiddun mengalami keambrukan. ${ }^{13}$

f. Periode Keenam (1248-1492M)

Pada periode ini, Islam hanya berkuasa di daerah Granada, di bawah dinasti Bani Ahmar (1232- 1492 M). Peradaban kembali mengalami kemajuan seperti di zaman Abdurrahman An-Nasir. Akan

${ }^{13}$ A. Syalabi, Sejarah dan Kebudayaan Islam, 76.

Humanistika: Vol. 7 No. 22021. 


\section{Islam di Spanyol : Jembatan Peradaban Islam ke Benua Eropa dan Pengaruhnya Terhadap Renaissance}

tetapi, secara politik, dinasti ini hanya berkuasa di wilayah yang kecil. Kekuasaan Islam yang merupakan pertahanan terakhir di Spanyol ini berakhir karena perselisihan orang-orang istana dalam merebutkan kekuasaan. ${ }^{14}$ Dan hal ini dapat di manfaatkan dengan baik oleh umat Kristen untuk kembali merebut kekuasaan terakhir yang dimiliki oleh umat Islam, umat Islam setelah itu dihadapkan pada dua pilihan, masuk Kristen atau pergi meninggalkan Spanyol. Pada tahun 1609 M, boleh dikatakan tidak ada lagi umat Islam di daerah itu. ${ }^{15}$

\section{Tentang Ihwal Pemerintahan}

Abd al-Rahman Ibn Mu'awiyah menginjakkan kakinya di Spanyol setelah lolos dari upaya pembunuhan atas dirinya ketika terjadi revolusi Abbasiyah pada 132H/750M. Ia dijuluki al-Dakhil, karena ia merupakan pangeran bani Umayyah pertama yang memasuki wilayah itu. Ia menyingkirkan Yusuf Ibn al-Rahman al-Rihri, Gubernur Andalusia yang tunduk di bawah kekuasaan Abbasiyah pada 756M. Pada 757M, ia menghapuskan nama khalifah Abbasiyah dari khotbah jum'at yang biasa dilakukan oleh gubernur sebelumnya, serta memplokamirkan wilayah tersebut lepas dari kekuasaan Abbasiyah. Sekalipun begitu, ad-Dakhil hanya menyebut dirinya sebagai amir,

\footnotetext{
${ }^{14}$ Badri Yatim, Sejarah Peradaban Islam, 99.

${ }^{15}$ Harun Nasution, Islam ditinjau dari berbagai aspeknya, Jilid II (Jakarta: UI Press, 1985), 82.
}

Humanistika: Vol. 7 No. 22021. 


\section{Irzak Yuliardy Nugroho}

karena menurut doktrin hukum orthodok (fiqh), kekhalifahan itu satu dan tidak bisa dibagi, menurut doktrin ini khalifah hanyalah kepala negara yang menguasai dua kota suci yakni Mekkah dan Madinah.

Al-Dakhil berhasil meletakkan pondasi dasar yang kokoh bagi tegaknya Daulah Bani Umayyah II di Spanyol. Selama 32 tahun masa kepemimpinannya, ia mampu mengatasi berbagai ancaman dari dalam maupun serangan musuh dari luar. Karena itulah ia dijuluki Rajawali Quraisy. Gelar amir tetap dipertahankan oleh para penerusnya sampai pada awal pemerintahan amir kedelapan Abd al-Rahman III (912$961 \mathrm{M}) .^{16}$

\section{Pengaruh Peradaban Islam Terhadap Kemajuan Peradaban Andalusia}

Lebih dari tujuh abad kekuasaan Islam di Spanyol, umat Islam telah mencapai kejayaannya di sana. Banyak prestasi yang mereka peroleh, bahkan, pengaruhnya membawa Eropa, kemudian dunia, kepada kemajuan yang lebih kompleks.

a. Kemajuan Intelektual

Spanyol adalah negeri yang subur. Kesuburan itu mendatangkan penghasilan ekonomi yang tinggi dan pada gilirannya banyak menghasilkan pemikir.

Masyarakat Spanyol Islam merupakan masyarakat majemuk yang terdiri dari komunitas-komunitas Arab (Utara dan

\footnotetext{
${ }^{16}$ Siti Maryam et.al, Sejarah Peradaban Islam: Dari Masa Klasik Hingga Modern, 81.
}

Humanistika: Vol. 7 No. 22021. 


\section{Islam di Spanyol : Jembatan Peradaban Islam ke Benua Eropa dan Pengaruhnya Terhadap Renaissance}

Selatan), Barbar (umat Islam yang berasal dari Afrika Utara), alShaqalibah (penduduk daerah antara Konstantinopel dan Bulgaria yang menjadi tawanan Jerman dan dijual kepada penguasa Islam untuk dijadikan tentara bayaran), Yahudi, Kristen Muzareb yang berbudaya Arab dan Kristen yang masih menetang kehadiran Islam. Semua komunitas itu, kecuali yang terakhir, memberikan saham intelektual terhadap terbentuknya lingkungan budaya Andalus yang melahirkan kebangkitan ilmiah, sastra, dan pembangunan fisik di Spanyol.

Kemajuan intelektual di Spanyol meliputi bidang keilmuan Filsafat, Sains, Fiqih, Musik dan Kesenian, Bahasa dan Sastra:

1) Sains

Ilmu-ilmu kedokteran, musik, matematika, astronomi, kimia dan lain-lain juga berkembang dengan baik. Abbas ibn Farnas termasyhur dalam ilmu kimia dan astronomi. Ialah orang pertama yang menemukan pembuatan kaca dari batu. ${ }^{17}$ Ibrahim ibn Yahya Al-Naqqashad terkenal dalam ilmu astronomi. Ia dapat menentukan waktu terjadinya gerhana matahari dan menentukan berapa lamanya. Ia juga berhasil membuat teropong modern yang dapat menentukan jarak antara tata surya dan bintang-bintang. Ahmad ibn Ibas daro Cordova adalah ahli dalam bidang obat-obatan. Umm AlHasan bint Abi Ja'far dan saudara perempuan Al-Hafidz adalah dua orang ahli kedokteran dari kalangan wanita. ${ }^{18}$

2) Fiqih

${ }^{17}$ A. Syalabi, Sejarah dan Kebudayaan Islam, 86.

${ }^{18}$ Badri Yatim, Sejarah Peradaban Islam, 102.

Humanistika: Vol. 7 No. 22021. 


\section{Irzak Yuliardy Nugroho}

Dalam bidang fiqih, Spanyol Islam dikenal sebagai penganut mazhab Maliki. Yang memperkenalkan mazhab ini di sana adalah Ziyad ibn Abd Al-Rahman. Perkembangan selanjutnya ditentukan oleh Ibn Yahya yang menjadi qadhi pada masa Hisyam ibn Abd Al-Rahman. Ahli-ahli fiqih lainnya di antaranya adalah Abu Bakr ibn Al-Quthiyah, Munzir ibn Sa'id Al-Baluthi, dan Ibn Hazm yang terkenal. ${ }^{19}$

3) Musik dan kesenian

Dalam bidang musik dan seni suara. Spanyol Islam mencapai kecemerlangan dengan tokohnya Al-Hasan ibn Nafi yang dijuluki Zaryab. Setiap kali diselenggarakan pertemuan dan jamuan, Zaryab selalu tampil mempertunjukkannya kebolehannya. Ia juga terkenal sebagai penggubah lagu. Ilmu yang dimilikinya itu diturunkan kepada anak-anaknya, baik pria maupun wanita, dan juga kepada budak-budak, sehingga kemasyhurannya tersebar luas. ${ }^{20}$

4) Bahasa dan Sastra

Bahasa Arab telah menjadi bahasa administrasi dalam pemerintahan Islam di Spanyol. Hal itu dapat diterima oleh orang-orang Islam dan non-Islam. Bahkan, penduduk asli Spanyol menomor duakan bahasa asli mereka. Mereka itu antara lain: Ibn Sayyidih, Ibn Malik pengarang Alfiyah, Ibn Khuruf, Ibn Al-Hajj, Abu Ali Al-Isybili, Abu Al-Hasan Ibn Usfur, dan Abu Hayyan Al-Gharnathi.

\footnotetext{
${ }^{19}$ Badri Yatim, Sejarah Peradaban Islam, 103.

${ }^{20}$ A. Syalabi, Sejarah dan Kebudayaan Islam, 88.
}

Humanistika: Vol. 7 No. 22021. 


\section{Islam di Spanyol : Jembatan Peradaban Islam ke Benua Eropa dan Pengaruhnya Terhadap Renaissance}

Seiring dengan kemajuan bahasa itu, karya-karya sastra banyak bermunculan, seperti Al-'Tqd al-Farid karya Ibn Abd Rabbih, al-Dzakhirah fi Mahasin Ahl al-Jazirah oleh Ibn Bassam, Kitab al-Qalaid buah karya Al-Fath ibn Khaqan, dan banyak lagi yang lain. ${ }^{21}$

b. Pembangunan Fisik

Penduduk Spanyol, baik Muslim ataupun bukan, memperoleh kesempatan yang sama untuk berperna serta dalam pembangunan negara. Oleh karena itu, daulah Bani Umayyah II yang merupakan inti kekuasaan Islam di Spanyol, mampu menempatkan Cordova sejajar dengan Konstantinopel dan Baghdad sebagai pusat peradaban dunia. Cordova menjadi penting sejak Samah Ibn Malik al-Khaulani menjadikan kota ini sebagai ibukota propinsi Andalusia menggantikan Sevilla pada tahun $719 \mathrm{M}^{22}$

Aspek-aspek pembangunan fisik yang mendapat perhatian umat Islam sangat banyak. Dalam perdagangan, jalan-jalan dan pasar-pasar dibangun. Demikian juga dibidang pertanian. Umat Islam juga memperkenalkan sistem irigasi dalam pertanian yang sebelumnya belum pernah dikenal. Disamping itu, orang-orang Islam juga memperkenalkan pertanian padi, perkebunan jeruk, kebun-kebun, dan tamantaman.

${ }^{21}$ Badri Yatim, Sejarah Peradaban Islam, 103.

${ }^{22}$ Siti Maryam et.al, Sejarah Peradaban Islam: Dari Masa Klasik Hingga Modern, 84.

Humanistika: Vol. 7 No. 22021. 


\section{Irzak Yuliardy Nugroho}

Industri disamping pertanian dan perdagangan, juga merupakan tulang punggung ekonomi Spanyol Islam. Di antaranya adalah tekstil, kayu, kulit, logam, dan industri barang-barang tembikar.

Namun demikian, pembangunan-pembangunan fisik yang paling menonjol adalah pembangunan gedung-gedung, seperti pembangunan kota, istana, mesjid, pemukiran, dan taman-taman. Di antara pembangunan yang megah adalah mesjid Cordova, kota Al-Zahra, Istana Ja'fariyah di Saragosa, tembok Toledo, istana Al-Makmun, mesjid Seville, dan istana Al-Hamra di Granada. ${ }^{23}$

\section{Faktor Penunjang Kemajuan Islam Spanyol}

Pada peradaban Islam Spanyol, kemajuan sangat ditentukan oleh adanya peguasa-penguasa yang kuat dan berwibawa, yang mampu mempersatukan kekuatan-kekuatan umat Islam, seperti Abd Al-Rahman Al-Dakhil, Abd AlRahman, Al-Wasith dan Abd Al-Rahman Al-Nasir.

Keberhasilan politik pemimpin-pemimpin tersebut ditunjang oleh kebijaksanaan penguasa-penguasa lainnya yang mampu mempelopori kegiatan-kegiatan ilmiah yang terpenting di antara penguasa dinasti Umayyah di Spanyol dalam hal ini adalah Muhammad Ibn Abd Al-Rahman (852886) dan Al-Hakam II Al-Muntashir (961-976).

Meskipun ada persaingan antara Abbasiyah di Baghdad dan Umayyah di Spanyol, hubungan budaya dari Timur dan Barat tidak selalu berupa peperangan. Sejak abad ke

${ }^{23}$ Badri Yatim, Sejarah Peradaban Islam, 104.

Humanistika: Vol. 7 No. 22021. 


\section{Islam di Spanyol : Jembatan Peradaban Islam ke Benua Eropa dan Pengaruhnya Terhadap Renaissance}

$11 \mathrm{M}$ dan seterusnya, banyak sarjana mengadakan perjalanan dari ujung barat wilayah Islam ke ujung timur, sambil membawa buku-buku dan gagasan-gagasan. Hal ini menunjukan bahwa, meskipun umat Islam terpecah dalam beberapa kesatuan politik, terdapat apa yang disebut kesatuan budaya dunia Islam.

Perpecahan politik pada masa Muluk Al-Thawa'if dan sesudahnya tidak menyebabkan mundurnya peradaban. Masa itu, bahkan merupakan puncak kemajuan ilmu pengetahuan, kesenian dan kebudayaan Islam Spanyol. Setiap dinasti (raja) di Malaga, Toledo, Seville, Granada, dan lain-lain berusaha menyaingi Cordova. Kalau sebelumnya Cordova merupakan satu-satunya pusat ilmu dan peradaban Islam di Spanyol, Muluk Al-Thawa'if berhasil mendirikan pusat-pusat peradaban baru yang di antaranya justru lebih maju. ${ }^{24}$

\section{Faktor Penyebab Kemunduran Islam Spanyol}

Terdapat beberapa faktor penyebab mundurnya peradaban Islam Spanyol, antara lain yaitu: ${ }^{25}$

a. Konflik Islam dengan Kristen

Para penguasa Muslim tidak melakukan Islamisasi secara sempurna. Mereka sudah merasa puas dengan hanya menagih upeti dari kerajaan-kerajaan Kristen taklukannya dan membiarkan mereka mempertahankan hukum dan adat mereka, termasuk posisi hirarki tradisional, asal tidak ada perlawanan bersenjata. Oleh karena itu, secara tidak

\footnotetext{
${ }^{24}$ Badri Yatim, Sejarah Peradaban Islam, 105-107

${ }^{25}$ Badri Yatim, Sejarah Peradaban Islam, 107-108.
}

Humanistika: Vol. 7 No. 22021. 
langsung kehadiran orang Arab Islam di Spanyol telah membuat rasa kebangsaan Spanyol Kristen meningkat. Dan ini menyebabkan sering terjadinya pertentangan antara Islam dan Kristen. Sehingga di abad ke $11 \mathrm{M}$ umat Islam mengalami kemunduran akan tetapi sebaliknya bagi umat Kristen yang mengalami kemajuan pesat.

b. Tidak Adanya Ideologi Pemersatu

Kalau di tempat-tempat lain, para mukallaf diperlakukan sebagai orang Islam yang sederajat, di Spanyol, sebagaimana politik yang dijalankan Bani Umayyah di Damaskus, orang-orang Arab tidak pernah menerima orang-orang pribumi. Setidak-tidaknya sampai abad $10 \mathrm{M}$, mereka masih memberi istilah ibad dan muwalladun kepada para mukallaf itu, suatu ungkapan yang dinilai merendahkan. Akibatnya, kelompokkelompok etnis non-Arab yang ada sering menggerogoti dan merusak perdamaian. Hal itu mendatangkan dampa besar terhadap sejarah sosio-ekonomi negeri tersebut. Hal ini menunjukan tidak ada ideologi yang dapat memberikan makna pemersatu, di samping itu kurangnya figur yang dapat menjadi personifikasi ideologi itu.

c. Kesulitan Ekonomi

Di paruh kedua masa Islam di Spanyol, para penguasa membangun kota dan mengembangkan ilmu pengetahuan dengan sangat serius sehingga lalai membina perekonomian. Akibatnya timbul kesulitan ekonomi yang amat memberatkan dan mempengaruhi kondisi politik dan militer.

Humanistika: Vol. 7 No. 22021. 


\section{Islam di Spanyol : Jembatan Peradaban Islam ke Benua Eropa dan Pengaruhnya Terhadap Renaissance}

d. Tidak Jelasnya Sistem Peralihan Kekuasaan

Hal ini menyebabkan perebutan kekuasaan di antara ahli waris. Bahkan, karena inilah kekuasaan Bani Umayyah runtuh dan Al-Thawaif muncul. Granada yang merupakan pusat kekuasaan Islam terakhir di Spanyol jatuh ke tangan Ferdinand dan Isabella, di antaranya juga disebabkan permasalahan ini.

e. Keterpencilan

Spanyol Islam bagaikan terpencil dari dunia Islam yang lain, selalu berjuang sendirian, tanpa mendapatkan bantuan kecuali dari Afrika Utara. Dengan demikian, tidak ada kekuatan alternatif yang mampu membendung kebangkitan Kristen di sana. ${ }^{26}$

\section{Lenyapnya Islam di Spanyol}

Setelah kejatuhan Granada tahun 1492, di Spanyol terus berlangsung apa yang disebut dengan proses pembersihan ummat Islam. Pada tahun 1499 suatu gerakan di bawah pimpinan Kardinal Ximenes de Cisneros memerintahkan pembakaran buku-buku agama Islam berbahasa Arab, yang kemudian diteruskan dengan inquisisi, yakni pemaksaan orang-orang Islam untuk bertobat (kembali kepada agama Katolik sebagaimana nenek moyangnya). Sejak saat itu mendung gelap menyelimuti kehidupan ummat Islam Spanyol. Fenomena yang sering ditemukan adalah banyaknya orang-orang Islam dengan sebutan muslim berselimut, yakni mereka yang secara lahiriyah mengikuti tata cara Katolik, namun dalam jiwanya masih terikat dengan Islam. Sebagai contoh, banyak

${ }^{26}$ Badri Yatim, Sejarah Peradaban Islam, 107-108.

Humanistika: Vol. 7 No. 22021. 


\section{Irzak Yuliardy Nugroho}

mereka yang ketika di luar menggunakan nama-nama baptis, namun ketika di rumah menggunakan nama-nama Islam (Arab) nya, mereka setelah menikah di gereja, kemudian setelah pulang mengulanginya dengan pernikahan secara Islam.

Tahun 1501 keluarlah maklumat Raja yang mengharuskan semua kaum muslimin di seluruh Castille dan Leon untuk kembali memeluk Katolik, atau mereka meninggalkan negara itu. Menyusul kemudian hal itu berlaku di Aragon pada tahun 1526. Tetapi karena perintah ini tidak begitu keras, maka masih banyak kaum muslimin yang tidak menghiraukan. Sebagai tindakan keras berikutnya adalah ketika tahun 1556 Raja Philip II mengumumkan Undang-Undang supaya orang islam yang masih tinggal di Spanyol untuk meninggalkan bahasa, kepercayaan, dan adat-istiadatnya, serta memerintahan untuk merusak semua tempat-tempat pemandian umum yang digunakan orang Islam. Waktu itu sempat terjadi beberapa pemberontakan, tetapi dapat dipadamkan oleh pemerintah. Pada tahun 1609 Raja Philip III mengeluarkan perintah resmi pengusiran semua muslimin dari wilayah Spanyol secara paksa. Salah satu kejadian yang mengharukan adalah ketika satu juta orang Islam dipaksa naik kapal dan dibawa ke pesisir Afrika atau negara-negara Islam yang jauh. ${ }^{27}$

${ }^{27}$ Yusran Asmuni, Dirasah Islamyiah II, (Jakarta : PT. Raja Grafindo Persada, 1996), 16

Humanistika: Vol. 7 No. 22021. 


\section{Islam di Spanyol : Jembatan Peradaban Islam ke Benua Eropa dan Pengaruhnya Terhadap Renaissance}

\section{Pengaruh Peradaban Islam Bagi Benua Eropa}

Kemajuan Eropa yang terus berkembang hingga saat ini banyak berhutang budi kepada khazanah ilmu pengetahuan Islam yang berkembang di periode klasik. Memang banyak saluran bagaimana peradaban Islam mempengaruhi Eropa, seperti Sicilia dan Perang Salib, tetapi saluran yang penting adalah Spanyol Islam.

Spanyol merupakan tempat yang paling utama bagi Eropa menyerap peradaban Islam, baik dalam bentuk hubungan politik, sosial, maupun perekonomian, dan peradaban antar negara. Orang-orang Eropa menyaksikan kenyataan bahwa Spanyol berada dibawah kekuasaan Islam jauh meninggalkan negara-negara tetangganya Eropa, terutama dalam bidang pemikiran dan sains di sampin bangunan fisik. Yang terpenting di antaranya adalah pemikiran Ibn Rusyd (1120-1198 M). Ia melepaskan belenggu taklid dan menganjurkan kebebasan berfikir. Ia mengulas pemikiran Aristoteles dengan cara memikat minat semua orang yang berpikiran bebas. Ia mengedepankan sunatullah menurut pengertian Islam terhadap pantheisme dan anthropomorphisme Kristen. Demikian besar pengaruhnya di Eropa, hingga di Eropa timbul gerakan Averroisme yang menuntut kebebasan berfikir. Pihak gereja menolak pemikiran rasional yang dibawa gerakan Averroisme ini.

Berawal dari gerakan Averroisme inilah di Eropa kemudian lahir reformasi pada abad ke-16 M dan rasionalisme

Humanistika: Vol. 7 No. 22021. 


\section{Irzak Yuliardy Nugroho}

pada abad ke $17 \mathrm{M} \cdot{ }^{28}$ Buku-buku Ibn Rusyd dicetak di Vinesia tahun 1481, 1482, 1483, 1489, dan 1500 M. Bahkan edisi lengkapnya terbit pada tahun 1553 dan 1557 M. Karyakaryanya juga diterbitkan pada abad ke 16 M di Napoli, Bologna, Lyonms, dan Atrasbourg, dan di awal abad ke $17 \mathrm{M}$ di Jenewa.

Pengaruh peradaban Islam termasuk didalamnya pemikiran Ibn Rusyd ke Eropa berawal dari banyaknya pemuda-pemuda Kristen Eropa yang belajar di Universitasuniversitas Islam di Spanyol, seperti universitas Cordova, Seville, Malaga, Granada, dan Salamanca. Selama belajar di Spanyol, mereka aktif menerjemahkan buku-buku karya ilmuwan Islam. Pusat penerjamahan iru sendiri berada di Toledo. Setelah pulan ke negerinya, mereka mendirikan sekolah dan universitas yang sama. Universitas pertama di Eropa adalah Universitas Paris yang didirikan pada tahun 1231 M, tiga puluh tahun setelah wafatnya Ibn Rusyd. Di akhir zaman pertengahan Eropa, baru berdiri 18 buah universitas. Di dalam universitas itu, ilmu yang mereka peroleh dari universitas-universitas Islam diajarkan, seperti ilmu kedokteran, ilmu pasti, dan filsafat. Pemikiran filsafat yang paling banyak adalah pemikiran Al-Farabi, Ibn Sina dan Ibn Rusyd.

Pengaruh ilmu pengetahuan Islam atas Eropa yang sudah berlangsung sejak abad ke $12 \mathrm{M}$ itu menimbulkan

\footnotetext{
${ }^{28}$ S. I. Poeradisastra, Sumbangan Islam kepada Ilmu dan Peradaban Modern, cet II, (Jakarta: P3M, 1986), 67.
}

Humanistika: Vol. 7 No. 22021. 


\section{Islam di Spanyol : Jembatan Peradaban Islam ke Benua Eropa dan Pengaruhnya Terhadap Renaissance}

gerakan kebangkitan kembali (renaissance) pusaka Yunani di Eropa pada abad ke $14 \mathrm{M}$. Berkembangnya pemikiran Yunani di Eropa kali ini adalah melalui terjemahan-terjemahan Arab yang dipelajari dan kemudian diterjemahkan kembali ke dalam bahasa Latin.

Adalah kebangkitan kembali kebudayaan Yunani klasik (renaissance) pada abad ke $14 \mathrm{M}$ ysng bermula di Italia, gerakan reformasi pada abad ke $16 \mathrm{M}$, rasionalisme pada abad ke $17 \mathrm{M}$ dan pencerahan (aufklarung) pada abad ke $18 \mathrm{M}{ }^{29}$

\section{KESIMPULAN}

Sebelum Islam hadir, terjadi kekacauan oleh kerajaan Gotic yang memaksa umat yahudi untuk di baptis. Hal ini membawa dampak perpecahan yang sangat signifikan diantara bangsa Spanyol itu sendiri. Keadaan ini dimanfaatkan dengan sangat baik oleh umat Islam dalam penaklukannya ke Spanyol. Dengan datangnya Islam ke Spanyol dapat diterima dengan baik oleh masyarakat Spanyol karena Islam membebaskan mereka untuk memeluk agama yang mereka yakini.

Masuknya Islam ke Spanyol diawali oleh tiga pahlawan, mereka yaitu, Tharif, Thariq dan Musa yang melakukan ekspansi dengan melakukan penyeberangan melalui selat diantara Maroko dan Eropa. Dan mereka berhasil menguasai Spanyol, kemenangan-kemenangan yang dicapai umat Islam nampak sangat begitu mudah. Hal itu tidak dapat dipisahkan dari faktor eksternal dan internal yang menguntungkan.

${ }^{29}$ Badri Yatim, Sejarah Peradaban Islam, 109.

Humanistika: Vol. 7 No. 22021. 


\section{Irzak Yuliardy Nugroho}

Masuknya Islam ke Eropa membawa dampak kemajuan yang sangat pesat dalam peradaban, antara lain kemajuan intelektual dan kemegahan bangunan. Banyak sekali manfaat yang didapat oleh peradaban Islam di Spanyol pada masa itu. Orangorang Arab banyak memperkenalkan hal-hal tentang pembangunan baru yang belum mereka temui sebelumnya.

Humanistika: Vol. 7 No. 22021. 
Islam di Spanyol : Jembatan Peradaban Islam ke Benua Eropa dan Pengaruhnya Terhadap Renaissance

\section{DAFTAR PUSTAKA}

A. Syalabi, Sejarah dan Kebudayaan Islam, Jilid II Cet. I (Jakarta: Pustaka Alhusna, 1983)

Asmuni, Yusran, Dirasah Islamyiah II, Jakarta : PT. Raja Grafindo Persada, 1996)

Brockelmaan, Carl, History of the Islamic Peoples, (London: Rotledge \& Kegan Paul, 1980)

Islam, M. H. (2019). Aplikasi dan Diferensiasi Pendidikan Islam. HUMANISTIKA: Jurnal Keislaman, 5(1), 73-95.

Islam, M. H. (2019). ISLAM AND CIVILIZATION (ANALYSIS STUDY ON THE HISTORY OF CIVILIZATION IN ISLAM). AlInsyiroh: Jurnal Studi Keislaman, 5(1), 22-39.

Islam, M. H. (2019, November). Model Pendekatan Halaqotul MuAllimin Al-Islamiyah dalam Membentuk Kepribadian Yang Rahmatan Lil Alamin Sebagai Identitas Kebangsaan di Pondok Pesantren AlMashduqiah. In Proceedings of Annual Conference for Muslim Scholars (Vol. 3, No. 1, pp. 491-503).

Islam, M. H. (2020). TOLERANCE LIMITATION IN FACING RELIGIOUS DIVERSITY BASED ON THE TEACHING OF ISLAM. Nazhruna: Jurnal Pendidikan Islam, 3(1), 1-13.

Islam, M. H., \& Aziz, A. (2020). Transformation of Pesantren in Maintaining Good Character. HUMANISTIKA: Jurnal Keislaman, 6(1), 35-48.

Humanistika: Vol. 7 No. 22021. 


\section{Irzak Yuliardy Nugroho}

Islam, M. H., \& Maskuri, M. (2020). Pembentukan Kepribadian Multikultural melalui Pendidikan Diversitas. Pendidikan Multikultural, 4(1), 23-44.

Nasution, Harun, Islam ditinjau dari berbagai aspeknya, Jilid II (Jakarta: UI Press, 1985)

Poeradisastra, S. I. Sumbangan Islam kepada Ilmu dan Peradaban Modern, cet II, (Jakarta: P3M, 1986)

Siti Maryam et.al, Sejarah Peradaban Islam: Dari Masa Klasik Hingga Modern, (Yogyakarta: LESFI, 2012), 79.

W. Arnold, Thomas, Sejarah Da'wah Islam, (Jakarta: Wijaya, 1983)

Watt, W. Montgomery, Kejayaan Islam: Kajian Kritis dari Tokoh Orientalis, (Yogyakarta: Tiara Wacana, 1990)

Yatim, Badri, Sejarah Peradaban Islam, (Jakarta: PT Rajagrafindo Persada, 2006)

Humanistika: Vol. 7 No. 22021. 